\title{
Response of phytoplankton communities to nitrogen input reduction in mesocosm experiments
}

\author{
V. Escaravage ${ }^{1, *}$, T. C. Prins ${ }^{1}$, C. Nijdam ${ }^{1}$, A. C. Smaal ${ }^{2}$, J. C. H. Peeters ${ }^{2}$ \\ 'Netherlands Institute of Ecology, Centre for Estuarine and Coastal Ecology, PO Box 140, 4400 AC Yerseke, \\ The Netherlands \\ ${ }^{2}$ National Institute for Coastal and Marine Management/RIKZ, PO Box 8039, 4330 EA Middelburg,
} The Netherlands

\begin{abstract}
The effects of a reduction in inorganic nitrogen input on phytoplankton communities (species composition, biomass and production) were studied in mesocosms. Experiments were conducted in 6 land-based mesocosms consisting of $3 \mathrm{~m}^{3}$ black polyethylene tanks. Light climate, temperature, mixing regime, and $\mathrm{P}$ and $\mathrm{Si}$ input were regulated to reproduce conditions comparable to those in Dutch coastal waters. Three levels of nitrogen availability were applied to the mesocosms used as replicates in 2 experiments, of $4 \mathrm{wk}$, in May-June and June-July 1994. In Expt 1, after $10 \mathrm{~d}$ in all treatments, diatoms (mainly Nitzschia delicatissima) became Si-limited and flagellates dominated phytoplankton. Within the group of flagellates, Phaeocystis sp. dominated numerically in the last week of the experiment when $\mathrm{N}$ was limiting and irradiance had increased. Phaeocystis sp. concentrations were higher in the mesocosms with the highest nitrogen load. In Expt 2, after the collapse of the initial diatom bloom due to Si-limitation (Thalassiosira sp.), an N-limited Phaeocystis sp. bloom developed and dominated the flagellate community. The decline of the Phaeocystis sp. bloom occurred together with the development of a second diatom bloom (Leptocylindrus danicus) under N-limitation. Phytoplankton biomass and production in these experiments reached levels measured in MERL mesocosm experiment for similar $\mathrm{N}$-additions. The response of primary production to $\mathrm{N}$-additions was tuned by the availability of light and other macronutrients. A saturation model could be fitted to observations with a set of parameters corresponding to representative ecophysiological characteristics. Phytoplankton species composition was related to season and resembled field communities observed in similar periods of the year. N-limited Phaeocystis colonial blooms were observed in mesocosms where $50 \%$ of the N-pool consisted of $\mathrm{NH}_{4}{ }^{+}$
\end{abstract}

KEY WORDS: Nitrogen - Mesocosm · Primary production - Nutrient limitation · Competition · Diatoms . Phaeocystis sp.

\section{INTRODUCTION}

Eutrophication in coastal and stratified areas is presumably responsible for the development of massive algal blooms, hypoxia and shifts in phytoplankton species composition in many areas of the world (Smayda 1990, Vollenweider et al. 1992). Large scale oxygen deficiencies in the German Bight of the North Sea, the

\footnotetext{
-Address for correspondence: National Institute for Coastal and Marine Management/RIKZ, PO Box 8039, 4330 EA Middelburg, The Netherlands.

E-mail: v.escaravage@rikz.rws.minvenw.nl
}

increase of phytoplankton biomass and the shift in its species composition prompted the decision of the Second North Sea Conference to halve the anthropogenic load of phosphorus and nitrogen into the North Sea by 1995. While this policy has been successful for phosphate, resulting in a $50 \%$ reduction of phosphorus concentrations in the Dutch coastal zone in 1995, loadings and concentrations of nitrogen have not shown a significant change (De Vries et al. 1998). Cadée \& Hegeman (1993) observed no reduction of the primary production in the Dutch Wadden Sea and suggested that it was the high $\mathrm{N}$-input that kept Dutch coastal phytoplankton at high levels of biomass and production 
despite the lowered $\mathrm{P}$ discharges. The role played by nitrogen in eutrophication has also been underlined by Peeters et al. (1995) in their study on oxygen depletion in the Oyster Ground area combining field research and a set of integrated ecosystem models. They concluded that reductions in phosphorus input into the North Sea should have no impact on the minimum oxygen levels in this area but with a $50 \%$ reduction in anthropogenic $\mathrm{N}$-load the minimum oxygen level should remain above $5 \mathrm{mg} \mathrm{l}^{-1}$ in the Oyster Ground region.

Anthropogenically induced eutrophication usually implies an increase of nitrogen and phosphorus rather than silicon and may therefore favour non-silicondependent algae over diatoms (Officer \& Ryther 1980, Smayda 1990, Schöllhorn \& Granéli 1993). In the Southern Bight of the North Sea, Phaeocystis sp. develops massive colonial blooms some weeks after the spring diatom peak (Gieskes \& Kraay 1975, Cadée \& Hegeman 1986). Cadée \& Hegeman (1986) reported an increase of both the Phaeocystis sp. spring bloom cell numbers (2-fold) and the duration of the spring bloom (8-fold) over the period 1973 to 1985 in the Marsdiep, The Netherlands. Whereas the diatom spring bloom in the Dutch coastal waters is ended by silicon limitation (Van Bennekom et al. 1975), Phaeocystis sp. can develop by utilizing the remaining nitrogen and phosphorus after the diatom bloom collapse (Veldhuis et al. 1986). It seems justified to relate the recent Phaeocystis sp. bloom amplification to increased eutrophication (increase of both $\mathrm{N}$ and P) (Cadée \& Hegeman 1986).

The question remains why, amongst all the nondiatom species, Phaeocystis sp. profits most from elevated nutrient availability. Riegman et al. (1992) experimentally investigated the ability of Phaeocystis sp. to compete for nutrients with other phytoplankton species, and to develop colonies under different kinds of nutrient limitation. Riegman et al. found: (1) Phaeocystis sp. was outcompeted by other flagellates (Emiliania huxleyi, Rhodomonas sp.) in P-limited continuous cultures; (2) under N-limitation, Phaeocystis sp. outcompeted the other flagellates; and (3) Phaeocystis sp. colony formation only occurred when $\mathrm{NO}_{3}{ }^{-}$was the sole $\mathrm{N}$-source and light and phosphorus were not limiting. They concluded that novel nuisance blooms are the possible result of major shifts in $\mathrm{N} / \mathrm{P}$ and $\mathrm{NH}_{4}{ }^{+} / \mathrm{NO}_{3}{ }^{-}$ratios rather than of a general $\mathrm{N}+\mathrm{P}$ enrichment effect.

Two mesocosm experiments were designed to answer the following questions: To what extent could a reduction in the $\mathrm{N}$-load induce a decrease of the phytoplankton biomass and production? What would be the effect of a reduction in the N-load on the phytoplankton species composition, with special emphasis on diatoms and flagellates (Phaeocystis sp.)?

\section{MATERIAL AND METHODS}

Experimental design. Experiments were carried out with 6 land-based mesocosms, located at the field station of the National Institute for Coastal and Marine Management/RIKZ near the mouth of the Oosterschelde estuary (SW Netherlands). The mesocosms consisted of black polyethylene tanks (height $3 \mathrm{~m}$, diameter $1.2 \mathrm{~m}$, volume $3000 \mathrm{l}$ ). In all experiments the mesocosms were filled with water from the Oosterschelde estuary on the evening before the experiments started. The water was continuously mixed with a rotating mixer. A scraper, made from a blade of polyethylene, was used to prevent the development of fouling organisms on the inner wall of the tank. Additional removal of fouling organisms was carried out manually, when necessary. Above the mesocosms, an optical diffusor of structured plexiglass (Groenendijk, Pl $20070 \mathrm{TK}$ ) was installed to ensure a homogeneous light gradient in the water column. Due to light reflection and absorption, $70 \%$ of the incident light passed through the diffusor. Heating of the mesocosms by solar radiation was diminished by spraying sea water on the outer wall of the tanks and by shielding the tanks from direct sunlight. Inorganic nutrients were continuously added to each of the mesocosms from stock solutions with a peristaltic pump. The mesocosms were continuously flushed with sea water at a rate of $100 \mathrm{l} \mathrm{d}^{-1}$, resulting in a residence time of the water of $30 \mathrm{~d}$. A $150 \mathrm{l}$ sediment container was placed on the bottom of each tank and filled with azoic sand with a median grain size of $210 \mu \mathrm{m}$ and an initial organic content of $0.16 \%$.

Two 151 benthic chambers were connected to the mesocosms and continuously flushed with mesocosm water $\left(70 \mathrm{l} \mathrm{h}^{-1}\right)$. The benthos chambers were especially designed to contain filter feeders such as mussels and to enable the quantification of fluxes of particulate and dissolved material between the bivalve community and the water column. The chambers were shielded from light. A $5 \mathrm{~cm}$ azoic sand layer was added to each chamber. Batches of 20 mussels were added to $1 \mathrm{cham}$ ber of each mesocosm. The grazing pressure exerted on phytoplankton biomass by this mussel density was approximately equal to the losses due to the flushing of the mesocosms with sea water $\left(0.03 \mathrm{~d}^{-1}\right.$; Prins et al. 1995a). The water of the 6 mesocosms was alternately pumped through an automated system containing a Turner fluorometer and a Stork-Servex Datasonde 3 with multiparameter water quality data logger for the continuous registration of fluorescence, oxygen, temperature, conductivity and $\mathrm{pH}$.

Two nutrient experiments were carried out, in MayJune (Expt 1) and in June-July 1994 (Expt 2). The mesocosms received nearly similar phosphorus and sil- 
icon additions which were close to field levels (see Prins et al. 1994). The nitrogen input was varied at 3 different levels to establish a gradient in DIN (dissolved inorganic nitrogen) additioning among the mesocosms: Treatments $\mathrm{L}$ (low), $\mathrm{M}$ (medium) and $\mathrm{H}$ (high). DIN was added as $\mathrm{NaNO}_{3}$, DIP (dissolved inorganic phosphorus) as $\mathrm{H}_{2} \mathrm{PO}_{4} \mathrm{Na}_{2}$ and $\mathrm{Si}$ as $\mathrm{Na}_{2} \mathrm{SiO}_{2} \mathrm{H}_{2} \mathrm{O}_{6}$. Nutrient ratios (N/P, N/Si) were of the same order of magnitude in both experiments; around the Redfield ratio in the highest addition, they decreased through the medium and low addition. The nutrient additions and ratios (including initial pools) are shown in Table 1.

In March-April 1994 a 'mussel experiment' was carried out to investigate the effect of varied mussel densities on phytoplankton dynamics (Prins et al. 1995a). From this experiment, data for the mesocosms loaded with 20 mussels were pooled with data from Expts 1 and 2 to investigate the dose-response effect between the $\mathrm{N}$-addition and the phytoplankton mean biomass and production.

Sampling and analytical procedures. Dissolved inorganic nutrients, DIN $\left(\mathrm{NH}_{4}{ }^{+}, \mathrm{NO}_{3}{ }^{-}, \mathrm{NO}_{2}{ }^{-}\right), \mathrm{PO}_{4}{ }^{3-}$ and $\mathrm{Si}(\mathrm{OH})_{4}$ concentrations ( $\left.\mathrm{mM}\right)$ were determined with an Autoanalyzer $\left(3 \times w^{-1}\right)$. Chlorophyll a (chl a) and phaeophytin a were analyzed by HPLC $\left(2 \times w k^{-1}\right)$. The chl a concentrations ( $\mathrm{mg} \mathrm{l}^{-1}$ ) measured in the discrete samples were used to convert the continuously measured fluorescence data to chl a. Phytoplankton cell numbers and species composition were determined $\left(2 \times w^{-1}\right)$ by the Utermöhl technique (Utermöhl 1958) after fixation with acid Lugol's iodine solution. For the quantitative analysis, 3 different functional/systematic groups were distinguished among the phytoplankters:

diatoms, Phaeocystis sp., and miscellaneous flagellates (mainly Cryptophyceae and unidentified microflagellates). Daily irradiance (PAR [photosynthetically active radiationl as mol photons $\mathrm{m}^{-2} \mathrm{~d}^{-1}$ ) was recorded directly under the optical diffusor with a LiCor Quantum SR sensor connected to a data acquisition system (description in Peeters et al. 1993a).

Light attenuation in the water column was measured $3 \times$ wk $^{-1}$ with a LiCor datalogger LI-1000 connected with a LiCor SPA-QUANTUM spherical sensor immersed at different depths over 2 vertical profiles in each mesocosm. The apparent attenuation coefficient $\left(K_{d}\right.$, in $\left.\mathrm{m}^{-1}\right)$ was calculated using linear regression

$$
\ln \left(\frac{i_{z}}{\dot{i}_{0}}\right)=-K_{d} \cdot z
$$

where $z$ : depth of the measurement $(\mathrm{m}), i_{0}$ : incident irradiance at surface ( $u \mathrm{~mol}$ photons $\mathrm{m}^{-2} \mathrm{~s}^{-1}$ ), and $i_{z}$ : incident irradiance at $z$ meters ( $\mu$ mol photons $\mathrm{m}^{-2} \mathrm{~s}^{-1}$ ). Light attenuation coefficients were linearly interpolated over time intervals when no measurements were made.

Daily primary production was measured by ${ }^{14} \mathrm{C}$ incubations twice a week. Water samples were incubated for $2 \mathrm{~h}$ with $185 \mathrm{kBq}{ }^{14} \mathrm{C}$-bicarbonates (Amersham) at irradiances of $0,10.6,24.4,53.8,136.2,281.1$, 663.8 and $1528.6 \mathrm{~mol}$ photons $\mathrm{m}^{-2} \mathrm{~s}^{-1}$ in a thermostated incubator. Samples were processed according to Peeters et al. (1991). Irradiance ( $i$, in $\mu \mathrm{mol}$ photons $\left.\mathrm{m}^{-2} \mathrm{~s}^{-1}\right)$ and production $\left(P\right.$, in $\left.\mathrm{mg} \mathrm{C} \mathrm{mg} \mathrm{chl}^{-1} \mathrm{~h}^{-1}\right)$ were used to fit a $P / I$ model following Eilers \& Peeters (1988):

$$
P=\frac{i}{a i^{2}+b i+c}
$$

Table 1. Net nutrient additions (L: low; M: medium; H: high) and corresponding molar ratios during the mesocosm experiments, including the initial nutrient pool in sea water, the experimental additions and the import/export due to the continuous flushing of the mesocosms. DIN, DIP: dissolved inorganic nitrogen

\begin{tabular}{|c|c|c|c|c|c|c|c|c|c|}
\hline \multirow[t]{2}{*}{ Expt } & \multirow[t]{2}{*}{ Treatment } & \multicolumn{5}{|c|}{$\begin{array}{c}\text { Net nutrient addition } \\
\text { (mmol) }\end{array}$} & \multicolumn{3}{|c|}{$\begin{array}{l}\text { Nutrient ratio } \\
(\mathrm{M} / \mathrm{M})\end{array}$} \\
\hline & & $\mathrm{NO}_{2}$ & $\mathrm{NH}_{4}$ & DIN & DIP & Silicate & $\mathrm{NH}_{4} / \mathrm{DIN}$ & $\mathrm{N} / \mathrm{P}$ & $\mathrm{N} / \mathrm{Si}$ \\
\hline 1 & L1 & - & 32 & 124.4 & 17.0 & 128.1 & 0.26 & 7.3 & 1.0 \\
\hline 1 & L. 2 & - & 32 & 123.6 & 17.0 & 128.6 & 0.26 & 7.3 & 1.0 \\
\hline 1 & M1 & - & 32 & 173.2 & 17.1 & 129.9 & 0.18 & 10.1 & 1.3 \\
\hline 1 & M2 & - & 32 & 171.7 & 16.9 & 128.7 & 0.19 & 10.2 & 1.3 \\
\hline 1 & $\mathrm{H} 1$ & - & 32 & 290.0 & 16.9 & 128.6 & 0.11 & 17.2 & 2.3 \\
\hline 1 & $\mathrm{H}^{2}$ & - & 32 & 290.4 & 16.9 & 129.9 & 0.11 & 17.2 & 2.2 \\
\hline 2 & L1 & 12 & 20 & 168.8 & 20.9 & 99.5 & 0.12 & 8.1 & 1.7 \\
\hline 2 & $\mathrm{~L} 2$ & 12 & 20 & 166.0 & 20.7 & 100.4 & 0.12 & 8.0 & 1.7 \\
\hline 2 & $\mathrm{M} 1$ & 12 & 20 & 230.0 & 20.8 & 99.9 & 0.09 & 11.1 & 2.3 \\
\hline 2 & M2 & 12 & 20 & 232.1 & 21.1 & 100.0 & 0.09 & 11.0 & 2.3 \\
\hline 2 & $\mathrm{H} 1$ & 12 & 20 & 371.3 & 20.9 & 100.1 & 0.05 & 17.8 & 3.7 \\
\hline 2 & $\mathrm{H} 2$ & 12 & 20 & 371.1 & 19.8 & 99.4 & 0.05 & 18.7 & 3.7 \\
\hline
\end{tabular}
and phosphorus
Parameters $a, b$ and $c$ were approximated by nonlinear regression (Nonlin module, SYSTAT statistical package). The closest $(a, b, c)$ estimate was used on days when no ${ }^{14} \mathrm{C}$-incubation was made. Daily primary production was estimated by combining daily values of surface irradiance, light attenuation coefficient and chl a concentration with $P / I$ curve characteristics.

Rating of the nutrient limitation. Deviations from the standard molar ratio P:N:Si = 1:16:16 (Gillbricht 1988) for dissolved inorganic nutrients were used as indicators for the first potentially limiting nutrient. The degree of nutrient limitation was estimated by comparing the water column nutrient concentrations with the following standard $K_{s}$ values for nutrient uptake by 

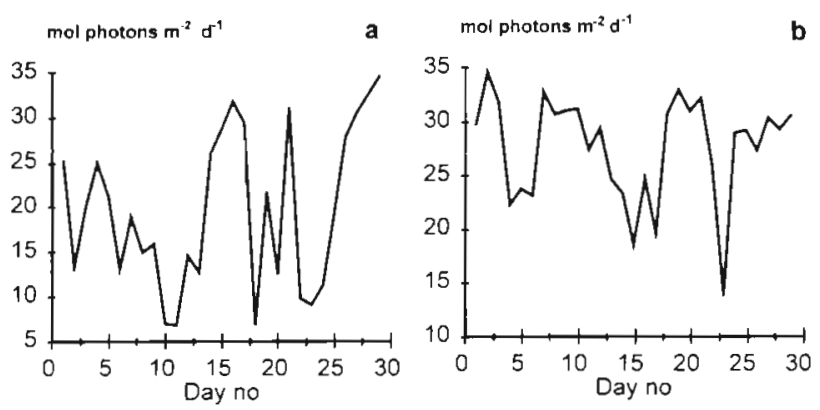

Fig. 1. Daily irradiance (PAR) measured during the mesocosm experiments: (a) Expt 1, (b) Expt 2

phytoplankton: $\mathrm{N}=2 \mu \mathrm{M} ; \mathrm{P}=0.5 \mu \mathrm{M} ; \mathrm{Si}=2 \mu \mathrm{M}$ (Peeters $\&$ Peperzak 1990, Peeters et al. 1993b). Whether one nutrient was actually limiting for phytoplankton was indicated by the co-occurrence of, firstly, a molar ratio relative to the other nutrients lower than the standard ratio and, secondly, a concentration lower than the standard $K_{s}$ values.

Statistical analysis. Whether treatments had a significant effect on phytoplankton variables (chlorophyll biomass, primary production, cell concentrations) was tested with analysis of variance (ANOVA). A mixed model ANOVA with replicate mesocosms nested within treatment was performed on the full sets of daily measurements after logarithmic transformation to obtain normality in the data distribution when necessary.

\section{RESULTS}

\section{Irradiance and potential light limitation}

Mean daily irradiance was higher in Expt 2 than in Expt 1 (26.78 and $19.74 \mathrm{~mol}$ photons $\mathrm{m}^{-2} \mathrm{~d}^{-1}$ respectively). The amplitude of variations of the daily irradiance was the largest in Expt 1 (Fig. 1). Marked decreases in daily irradiance were observed on Days 10, 18 and 22 in Expt 1, on Day 23 in Expt 2.

\section{Dissolved nutrient concentrations and potential nutrient limitation}

Since nitrogen was exclusively added in $\mathrm{NO}_{3}$ form, the $\mathrm{NH}_{4}{ }^{+}$fraction present in mesocosm water originated from the initial seawater filling or internal regeneration. As a result, in both experiments, $\mathrm{NH}_{4}{ }^{+}$concentrations were below $1 \mu \mathrm{M}$ in most cases.
During periods when DIN concentrations were low, the fraction due to $\mathrm{NH}_{4}$ could nevertheless represent about $80 \%$ of the inorganic nitrogen pool (Fig. 2).

Expt 1. After a short accumulation period, the concentrations of DIN, DIP and silicate decreased in all mesocosms after Day 5. Between Days 9 and 17, $\mathrm{Si}$ concentrations remained around $0.3 \mu \mathrm{M}$ in all mesocosms, whereas DIP concentrations increased again (more pronounced in mesocosms with the lowest $\mathrm{N}$-addition, L1 and L2). After Day 17, Si concentrations increased again in all mesocosms, especially in Mesocosm H1. During the same period, the DIN concentrations also increased in Mesocosm $\mathrm{H} 1$ whereas they remained at a relatively low level in the other mesocosms. In the last week of the experiment, the DIN and silicate concentrations decreased in Mesocosm $\mathrm{H} 1$ to levels similar to those in the other mesocosms.
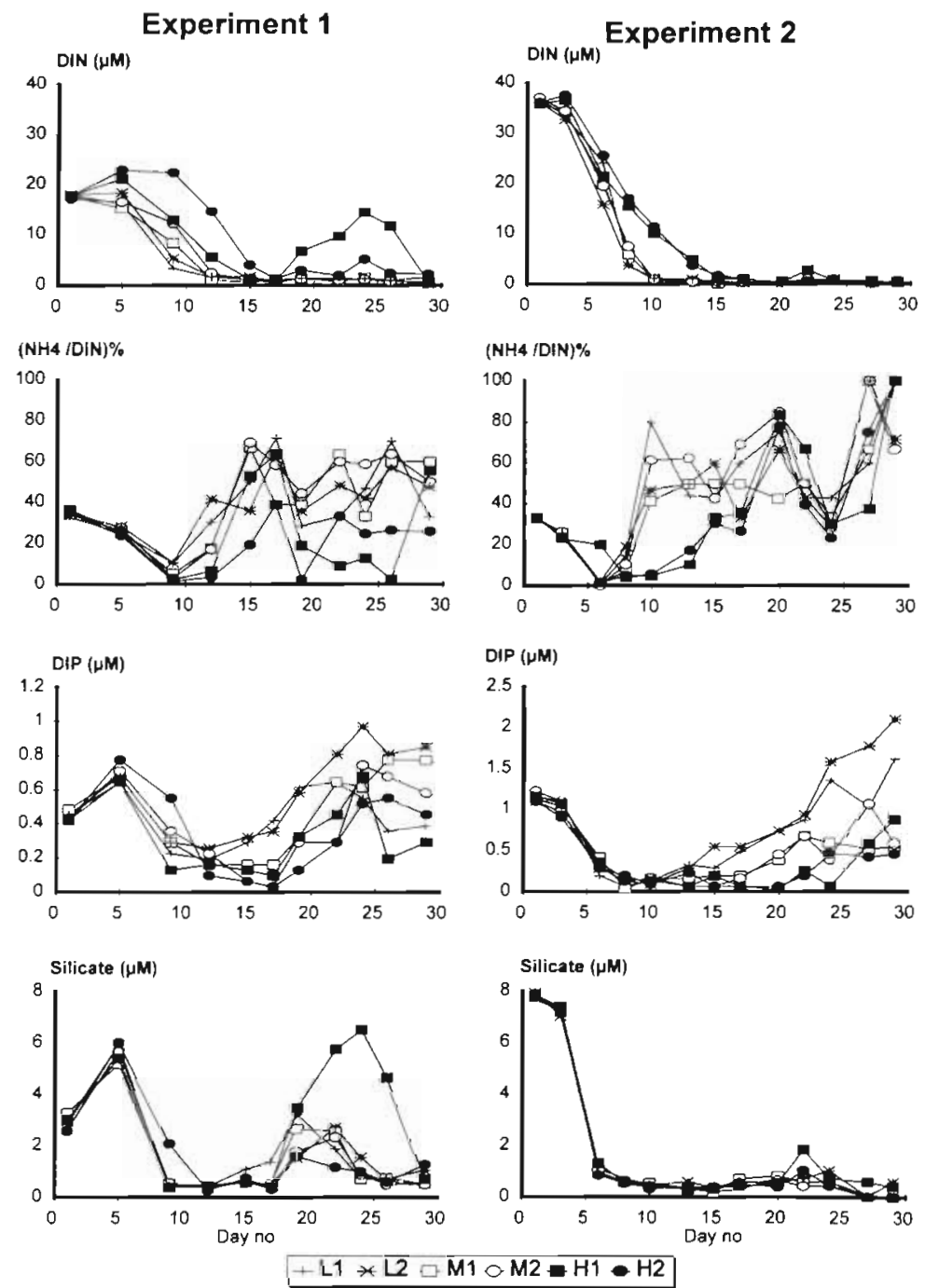

Fig. 2. Dissolved nutrient concentrations (DIN, DIP and Si) and $\mathrm{NH}_{4} / \mathrm{DIN}$ percentage measured during the mesocosm experiments 


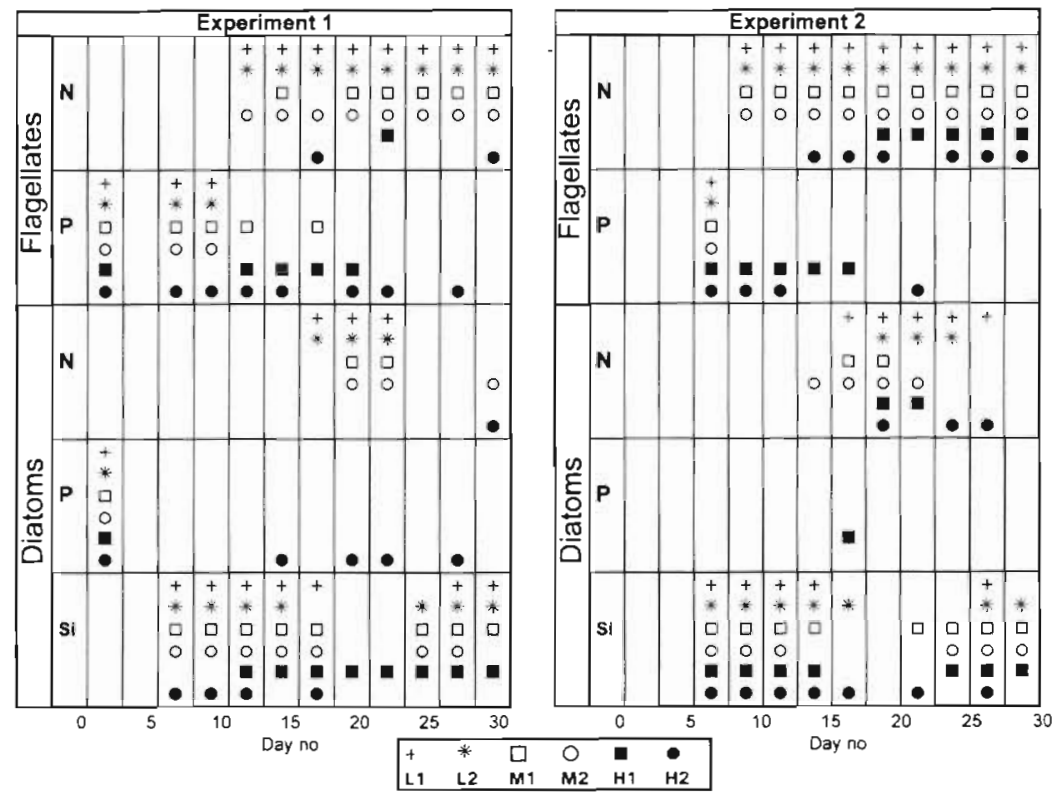

Fig. 3. Periods of potential diatom and flagellate nutrient limitation identified by the different treatments in both experiments (see 'Material and methods' for details)

Expt 2. The concentrations of all the nutrients decreased in the 6 mesocosms from the beginning of the experiment. On Day 10, DIN and silicate concentrations reached their lowest levels in the Treatments $L$ and $M$ and remained stable throughout the experiment. From Day 10 on. DIP concentrations increased again in Treatments $L$ and $M$, with the largest increase in Treatment $L$. In the mesocosms with the highest $\mathrm{N}$ addition $(\mathrm{H} 1, \mathrm{H} 2)$, the DIN concentrations reached their lower level only after Day 15, and the DIP concentrations increased after Day 20. The Si concentrations in Mesocosms $\mathrm{H} 1$ and $\mathrm{H} 2$ resembled those measured in the other mesocosms.

Both diatoms and flagellates were initially P-limited in Expt 1, whereas no nutrient limitation was measured on the first day of Expt 2 (Fig. 3). In both experiments, nitrogen limitation intensified with time and against the $\mathrm{N}$-addition gradient for the non-diatoms, whereas silicon was most of the time the first limiting nutrient for diatoms.

\section{Phytoplankton biomass (Fig. 4)}

Expt 1. Chl a concentrations increased similarly in the 6 mesocosms until Day 10 . After a short decline, concentrations increased again in Treatments $H$ and $M$ whereas they remained lower in Treatment L. Between Days 13 and 20, chl a concentrations declined in all mesocosms. During this period the concentrations generally ranked following the $\mathrm{N}$-addition gradient, except for Mesocosm H1, where chl a concentrations declined even below concentrations in mesocosms with lowest $\mathrm{N}$-addition between Days 20 and 26. After Day 23, chl a concentrations increased again in the 6 mesocosms.

Expt 2. Between Days 1 and 10, chl a concentrations had a similar peak in all mesocosms. Afterwards, 2 periods of growth were observed, in both cases the concentration increase was steeper in the mesocosms with higher $\mathrm{N}$-additions. The replication of the chl a concentrations within each treatment was well achieved and the concentrations clearly followed the $\mathrm{N}$-additions.

For both experiments ANOVA concluded that the treatment ( $\mathrm{N}$-addition gradient) had a significant effect on the chl a concentrations (Expt 1: $F_{\text {ratio }}=13.785$, $\mathrm{p}=0.031 ;$ Expt 2: $\left.F_{\text {ratio }}=282, \mathrm{p}<0.001\right)$.

\section{Primary production (Fig. 5)}

Expt 1. Daily primary production showed 2 periods of increase (Days 0 to 13 and 20 to 27) for all mesocosms, separated by a period with reduced activities.

Expt 2. Daily primary production increased during the first week to above $5 \mathrm{~g} \mathrm{C} \mathrm{d}^{-1}$. Afterwards, daily primary production declined in all mesocosms and fluctuated around $1,1.5$ and $2 \mathrm{~g} \mathrm{C} \mathrm{d}^{-1}$ for the $\mathrm{L}, \mathrm{M}$ and $\mathrm{H}$ treatments respectively. In the last week of the experiment primary production significantly increased particularly in Treatment $\mathrm{H}$.
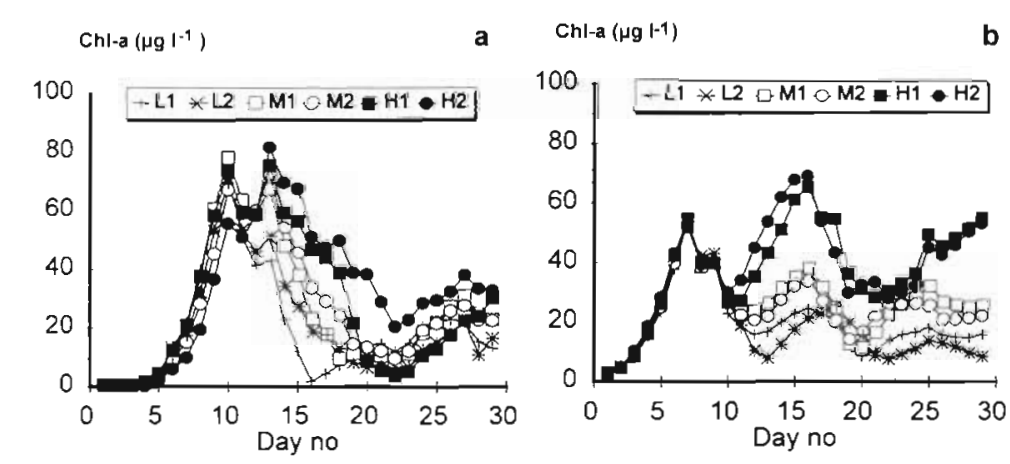

Fig. 4. Chl a concentrations measured during the mesocosm experiments: (a) Expt 1, (b) Expt 2. Between sampling dates (twice a week), chl a concentrations were estimated from continuous fluorescence measurements 


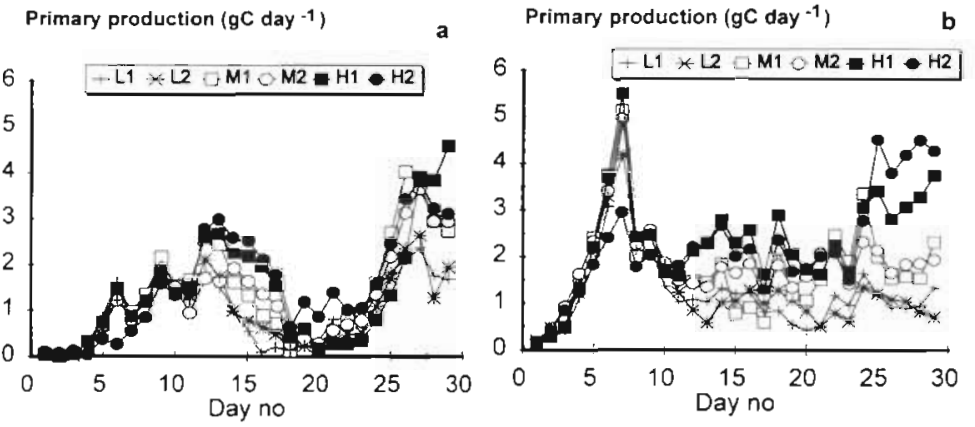

Fig. 5. Daily primary production measured during the mesocosm experiments: (a) Expt 1, (b) Expt 2. Measurements were made twice a week; between sampling dates, primary production was calculated from interpolated photosynthetic parameters and daily values of chlorophyl concentrations (Fig. 4) and irradiance (Fig. 1)

For both experiments it could be demonstrated by ANOVA that the N-treatment had a significant effect on the primary production (Expt 1: $F_{\text {ratio }}=23.08$, $\left.\mathrm{p}=0.015 ; \operatorname{Expt} 2: F_{\text {ratio }}=260, \mathrm{p}<0.001\right)$.

\section{Dose-response relationship between nutrient addition and phytoplankton biomass and production}

Results of both N-gradient experiments were pooled together with the results of mussel experiments (mesocosms with same mussel density as in Expts 1 and 2) to investigate the consistency of a general dose-response relationship between nitrogen additions and phytoplankton biomass and production (Table 2). Chl a concentrations exhibited a significant linear relationship with the nitrogen addition $\left(r^{2}=0.85, p<0.001\right)$ (Fig. 6). The relationship was less satisfactory for the daily primary production $\left(\mathrm{r}^{2}=0.32, \mathrm{p}=0.02\right)$. When Treatments $\mathrm{L}$ and $\mathrm{M}$ are considered, a linear model described adequately ( $p<0.001$ ) the relationship between nutrient addition and mean primary production (Fig. 6). This regression line failed however to describe the lower production rates measured in Mesocosms $1 \mathrm{H}$ and $2 \mathrm{H}$ and the mussel experiment when $\mathrm{N}$ additions were above ca $250 \mathrm{mmol}$. Possible factors responsible for the limited phytoplankton development in Mesocosms $1 \mathrm{H}$ and $2 \mathrm{H}$ and during the mussel experiment are: (1) Primary production was a function of light availability as well. When light availability was increased, the same nitrogen addition led to higher levels of production. (2) Above a certain N-addition, a switch in nutrient ratio occurred, allowing other nutrients to become lim-
Table 2. Net nitrogen addition (mmol), mean daily irradiance (PAR, mol photons $\left.\mathrm{m}^{-2} \mathrm{~d}^{-1}\right)$, mean chlorophyll concentrations $\left(\mathrm{mg} \mathrm{l}^{-1}\right)$, mean daily primary production ( $\mathrm{g} \mathrm{C} \mathrm{m}^{-2} \mathrm{~d}^{-1}$ ) measured during the 2 mesocosm experiments and a 'mussel' (Mus) experiment also carried out in 1994

\begin{tabular}{|lccccc|}
\hline Expt & Treatment & N-load & Irradiance & Chl a & Primary production \\
\hline 1 & L1 & 124 & 19.74 & 20.0 & 1.02 \\
1 & L2 & 124 & 19.74 & 20.0 & 0.97 \\
1 & M1 & 173 & 19.74 & 25.6 & 1.39 \\
1 & M2 & 172 & 19.74 & 25.9 & 1.27 \\
1 & H1 & 290 & 19.74 & 28.0 & 1.42 \\
1 & H2 & 290 & 19.74 & 33.0 & 1.56 \\
2 & L1 & 169 & 26.8 & 19.5 & 1.25 \\
2 & L2 & 166 & 26.8 & 18.4 & 1.28 \\
2 & M1 & 230 & 26.8 & 25.8 & 1.75 \\
2 & M2 & 232 & 26.8 & 24.2 & 1.83 \\
2 & H1 & 371 & 26.8 & 38.0 & 2.31 \\
2 & H2 & 371 & 26.8 & 38.7 & 2.25 \\
Mus1 & a & 383 & 16.2 & 33.1 & 1.17 \\
Mus1 & b & 383 & 16.2 & 39.1 & 1.43 \\
\hline
\end{tabular}

iting for primary production. Any further increase in $\mathrm{N}$-addition did not induce a corresponding linear increase of primary production.

This hypothesis was tested by investigating to what extent a single saturation model was able to describe the observations made in these 3 experiments. This model was inspired by the model proposed by Monod (1942) to describe the relationship between growth rate $(\mu)$ and external nutrient concentration $(\langle s\rangle)$ during steady state: $\mu=\mu_{\max }\left[\langle S\rangle /\left(K_{s}+\langle s\rangle\right)\right]$, where $\mu_{\max }$ : the maximal growth rate when nutrients are not limiting and $K_{s}$ : the half saturation constant for growth. This model was originally designed to describe nutrient-limited cultures where light was maintained at saturating levels. When light varies, a second term has to be added to the model to account for light controi. Following the $P / I$ formula by Eilers \& Peeters (1988), phytoplankton growth is a linear function of light $(\mu=a I)$ for light intensity below $I_{\text {opt }}$ and when no nutrient limitation is considered. By replacing $\mu_{\max }$ by aI in the Monod equation, the model accounts for both nutrient and light control. The Monod and Eilers \& Peeters models were developed at the scale of individual cell growth with instantaneous light intensity and ambient nutrient concentrations. Here we apply a similar model to describe processes at the scale of mean daily primary production with mean daily irradiance and nitrogen addition:

$$
P P R O D=(a \cdot I R R) \frac{N A d d}{N A d d+b}
$$

where PPROD: mean daily production $\left(\mathrm{g} \mathrm{C} \mathrm{m}^{-2} \mathrm{~d}^{-1}\right), I R R$ : mean daily irradiance (mol photons $\mathrm{m}^{-2} \mathrm{~d}^{-1}$ ), NAdd: $\mathrm{cu}$ - 

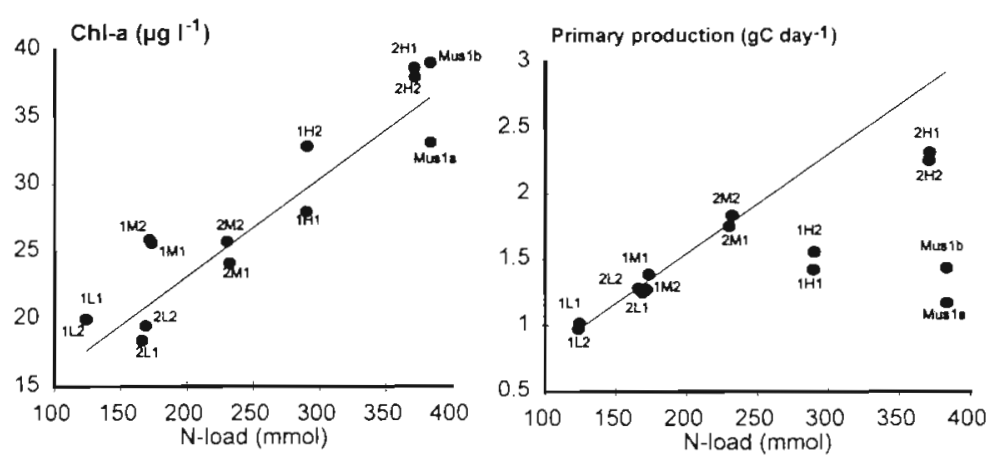

Fig. 6. Mean chl a concentrations and mean daily primary production against net nitrogen load measured during mesocosm experiments and a mesocosm 'mussel' experiment also performed in 1994. Data points: experiment number (1,2, Mus1), followed by treatment letter for nitrogen gradient experiments ( $L, M$, or $H)$, followed by number or letter of replicate $(1,2$, a or b). Data are plotted against cumulative nitrogen addition. Mesocosms $1 \mathrm{H}, 2 \mathrm{H}$ and Mus 1 were excluded from the regression analysis of primary production against the nitrogen addition (see text for details)
NONLIN module of the SYSTAT statistical software package and simulated production curves were calculated for each experiment (Fig. 7). Parameter values were $a=0.141$ ( $\mathrm{g} \mathrm{C} \mathrm{mol}^{-1}$ photons) and $b=270.9$ (mmol); predictions of the model were relatively close to observations $\left(\mathrm{r}^{2}=0.894\right.$, $\mathrm{p}<0.01, \mathrm{n}=14$ ). The model adequately described the combined effect of $N$ and light at relatively low light levels.

\section{Phytoplankton species composition and abundance (Fig. 8)}

Three systematic groups were distinguished in the quantitative study of phytoplankton: diatoms, Phaeocystis sp. and mulative nitrogen addition ( $\mathrm{mmol}$ ), a, $b$ : parameters to be calibrated.

The model produces an estimate of the production rate, a linear function of irradiance $(a \cdot I R R)$, that is modulated by an expression representing all the limiting factors related to high nitrogen additions: saturation of the primary production, increase of self-shading effect and activation of limitation by other nutrients than nitrogen. Parameters a and $b$ were calibrated within the

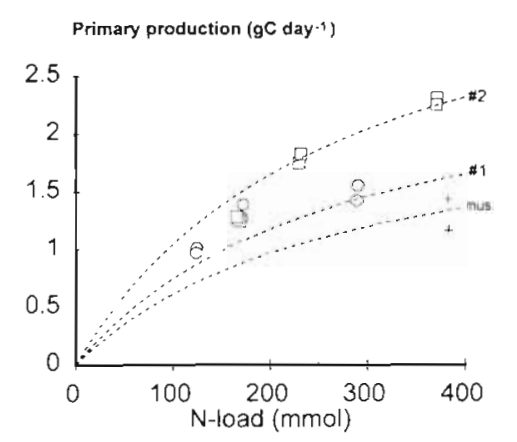

Fig. 7. Mean daily primary production measured during the mesocosm experiments $(0$, Expt $1 ; \square$, Expt 2) and 1 mesocosm 'mussel' experiment $(+)$ also performed in 1994. Data are plotted against net nitrogen load. The output of the saturation model obtained by fitting Eq. (3) to these data is also plotted for the mean irradiances measured during Expt 1 (㭋), Expt $2(\# 2)$ and the mussel experiment (mus.)
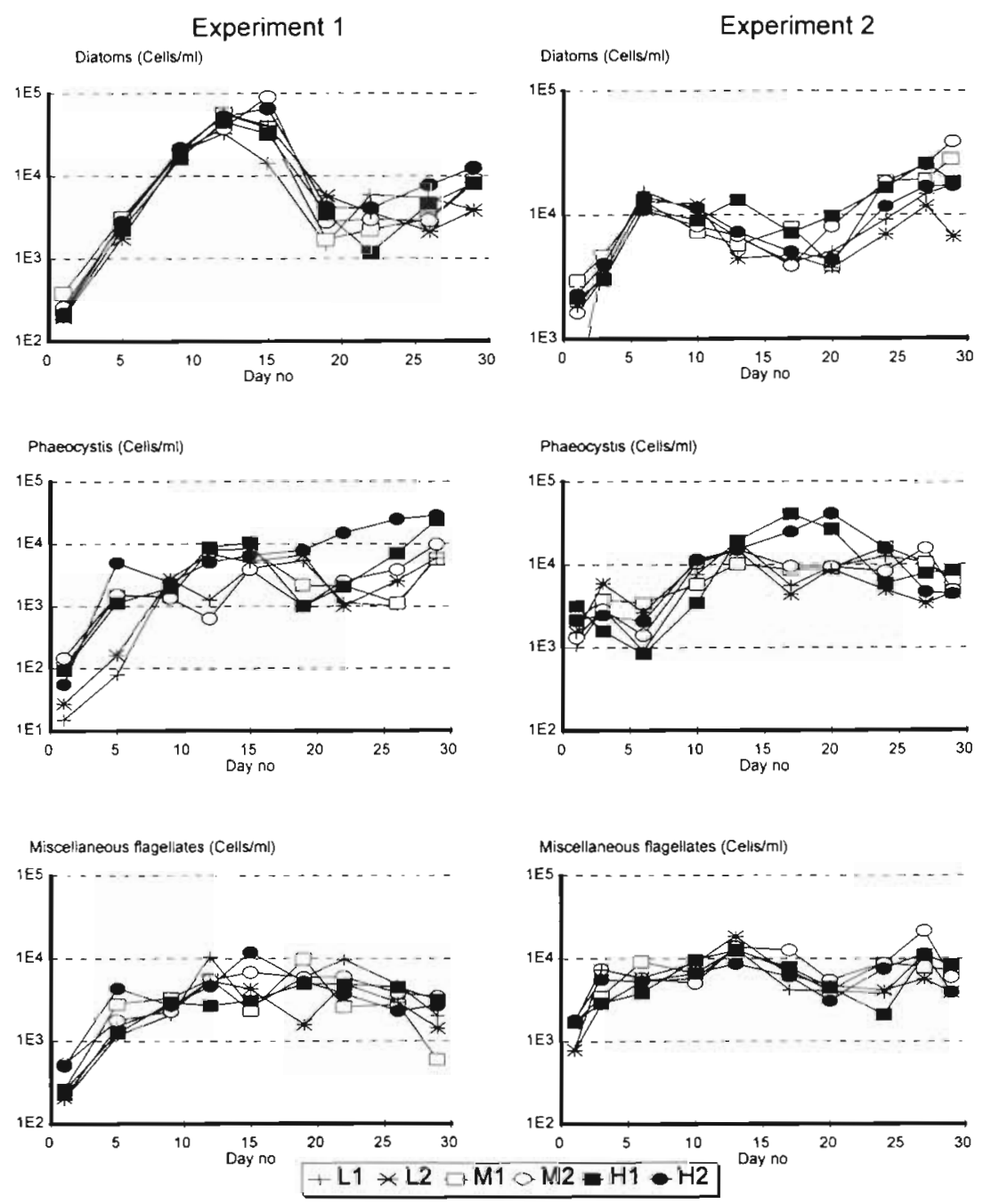

Fig. 8. Total diatom, total Phaeocystis sp. and total miscellaneous flagellate concentrations during the mesocosm experiments 
miscellaneous flagellates mainly composed of Cryptophyceae and small unidentified microflagellates.

Expt 1. Diatoms grew in a similar way in the 6 mesocosms until Day 12 to concentrations above 30000 cells $\mathrm{ml}^{-1}$. From Day 15 diatom concentrations sharply decreased in all mesocosms until Day 18 (around 3000 cells $\mathrm{ml}^{-1}$ ). Diatom concentrations increased again between Days 22 and 29, especially in the mesocosms with high $\mathrm{N}$-additions.

When the whole experiment was considered, no significant difference was found in the diatom concentration among the treatments. During the last week of the experiment, diatom concentrations were higher in Treatments $\mathrm{H}$ and $\mathrm{M}$ than in Treatment $\mathrm{L}$ (ANOVA, $F_{\text {ratio }}=$ 12.1, $\mathrm{p}=0.04$ ). The first diatom development was mainly due to Nitzschia delicatissima together with Chaetoceros $\mathrm{sp}$. The second diatom development mainly consisted of N. seriata, Eucampia zoodiacus, Rhizosolenia sp. and Chaetoceros sp. No major differences appeared in the species composition among the 3 treatments.

Phaeocystis sp. concentrations increased until Day 15 in the 6 mesocosms to values between 2000 and 10000 cells ml $\mathrm{ml}^{-1}$. Between Days 15 and 19, the Phaeocystis $\mathrm{sp}$. concentrations decreased in Mesocosm $\mathrm{H1}$ far below the concentrations measured in Mesocosm H2. Between Days 19 and 26, Phaeocystis sp. concentrations increased rapidly in the 2 mesocosms with the highest $\mathrm{N}$-addition whereas they almost stabilized in the other mesocosms between 5000 and 10000 cells $\mathrm{ml}^{-1}$. Significant differences in Phaeocystis sp. concentration among the treatments only occurred during the last week of the experiment for Treatment $H$ versus Treatments $\mathrm{L}$ and M (ANOVA, $\left.F_{\text {ratso }}=17.1, \mathrm{p}=0.026\right)$.

In all mesocosms, the miscellaneous flagellate concentrations increased during the first half of the experiment and decreased during the second half of the experiment. Concentrations of miscellaneous flagellates did not show significant differences among the treatments (ANOVA, $F_{\text {ratio }}=0.01, \mathrm{p}>0.05$ ).

Expt 2. Diatom concentrations sharply increased in all mesocosms between Days 1 and 6 to more than 10000 cells $\mathrm{ml}^{-1}$. From Days 6 to 20, concentrations decreased in all the mesocosms; they increased again after Day 20. During the last week of the experiment, diatom concentrations continued to increase in Treatment $M$ whereas they stabilized or decreased in Treatments $\mathrm{H}$ and $\mathrm{L}$. No significant difference in diatom concentration was found among the treatments. The first diatom development (until Day 6) was dominated by Thalassiosira sp. The second development consisted mainly of Leptocylindrus danicus. Between these 2 growth periods, diatoms were dominated by Chaetoceros sp. and Rhizosolenia shrubsolei.

Phaeocystis sp. concentrations increased in all mesocosms until Day 13 between 10000 and 20000 cells
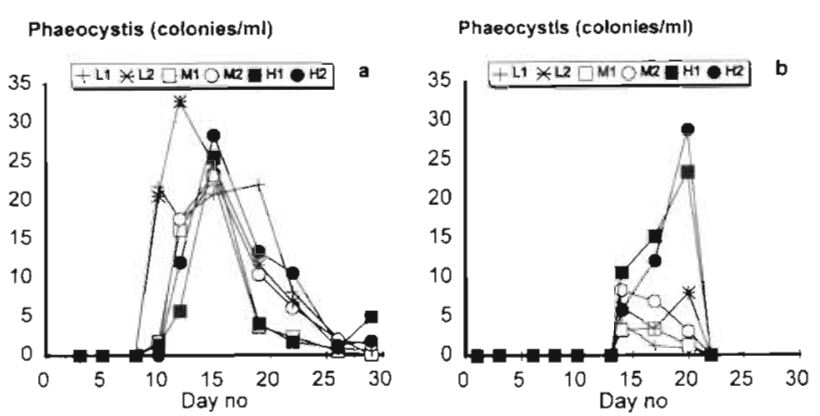

Fig. 9. Phaeocystis sp. colony concentrations measured during the mesocosm experiments: (a) Expt 1, (b) Expt 2

$\mathrm{ml}^{-1}$ ). Phaeocystis sp. concentrations continued to increase in Mesocosms $\mathrm{H} 1$ and $\mathrm{H} 2$ until Day 20 whereas they decreased in the other mesocosms. After Day 20 Phaeocystis sp. concentration also decreased in Treatment $\mathrm{H}$ and reached leveis similar to other treatments during the last week of the experiment. When the whole experimental period is considered, Phaeocystis sp. concentrations were significantly higher in Treatment $H$ than in Treatments $M$ and L (ANOVA, $F_{\text {rato }}=39.98, \mathrm{p}=0.007$ ).

In all mesocosms, miscellaneous flagellate concentrations showed 2 periods of growth, up to Day 13 and between Days 19 and 27, and did not show significant differences among the treatments (ANOVA, $F_{\text {ratio }}=2.44, \mathrm{p}>0.05$ ).

In both experiments, Phaeocystis sp. developed colonial blooms (Fig. 9). In Expt 1, the Phaeocystis sp. colonial bloom lasted approximately $10 \mathrm{~d}$, with maximum colony concentrations around Day 15 and little or no difference among treatments. In Expt 2, the Phaeocystis sp. colonial bloom occurred between Days 13 and 22 ; the highest concentrations were found in the mesocosms with the highest nitrogen addition. In the latter mesocosms, colony concentrations dropped from around 25 colonies $\mathrm{ml}^{-1}$ to 0 within $2 \mathrm{~d}$ (Days 20 to 22 ).

In both experiments, it was observed that, around the third week of the experiment, the diatoms in the mesocosms with relatively low $\mathrm{N}$-addition ( $\mathrm{M}$ and $\mathrm{L}$ ) had a remarkably low number of chloroplasts (empty cells) when compared with the diatoms in mesocosms with high $\mathrm{N}$-addition (full cells).

\section{DISCUSSION}

Delayed and weakened phytoplankton response due to initial nutrient pool

On Day 1 all mesocosms had the same nutrient concentrations, and the initial nitrogen pool first had to be consumed (by phytoplankton) to allow the establish- 
ment of a gradient in nitrogen availability among treatments. It took almost 15 and $10 \mathrm{~d}$ in Expts 1 and 2 respectively to exhaust the initial nitrogen pool. Afterwards, nitrogen limitation appeared in the mesocosms with the lowest $\mathrm{N}$-addition in both experiments. This initial period with similar development of the phytoplankton in all mesocosms was the main cause for the fact that the only significant difference in Expt 1 was found between Treatments $\mathrm{L}$ and $\mathrm{H}$.

\section{Mesocosms, stochasticity and treatments effects}

Discrepancies observed between Mesocosms $\mathrm{H} 1$ and $\mathrm{H} 2$ in Expt 1 with respect to the chlorophyll concentrations illustrate the interdependency of the repeated observations. Major discrepancies between Mesocosms $\mathrm{H} 1$ and $\mathrm{H} 2$ were measured from Day 13 onwards, when chlorophyll concentrations decreased in all mesocosms but reached lower levels in Mesocosm H1 than in Mesocosm H2. A correct assessment of the processes at play in these mesocosms implies consideration of the day-to-day dynamics rather than plain comparison of the levels reached by the biological variables. It appears that the main divergence between Mesocosms $\mathrm{H} 1$ and $\mathrm{H} 2$ was restricted to 2 observations. Between Days 17 and 18, chlorophyll concentrations decreased by $5.2 \mu \mathrm{g} \mathrm{l}^{-1}$ in Mesocosm $\mathrm{H} 1$ whereas they increased in Mesocosm $\mathrm{H} 2$ by $2.4 \mathrm{\mu g}^{-1}$. Between Days 19 and 20 they decreased by $13 \mu \mathrm{gl}^{-1}$ in Mesocosm $\mathrm{H} 1$ but just by $0.5 \mu \mathrm{g} \mathrm{l}^{-1}$ in Mesocosm H2. These 2 periods corresponded with sharp decreases of surface irradiance (Fig. 1). What was actually observed on these 2 particular days was a faster decay of the phytoplankton biomass in Mesocosm H1 than in Mesocosm $\mathrm{H} 2$ occurring together with a worsening of the light climate combined with potential nutrient limitation (Fig. 3). Since most external factors (nutrient supply, light, mixing) were similar in both mesocosms, a difference in grazing intensity represents the most straightforward hypothesis to explain the higher biomass losses observed in Mesocosm H1. This hypothesis is corroborated by observations by Wetsteyn \& Vink-Lievaart (1995), who found concentrations of aloricate ciliates 8 times higher in Mesocosm H1 than in Mesocosm H2 around Day 15, 8000 and 1000 ind $\mathrm{l}^{-1}$ respectively.

This example illustrated to what extent effects of localised events could propagate in time and induce changes in biological variables at the scale of the whole experiment. In the same way, whereas nutrient additions were kept uniform within each treatment and distinct among treatments, phytoplankton faced extended changes in nutrient availability. As a result, large variations and an associated overlap of phytoplankton characteristics among treatments were observed. These variations are better interpreted as the continuous adaptation of phytoplankton to rapidly changing conditions rather than as a straightforward response to the treatments. Consequently it seems overcritical to consider the variance attached to the experimental average of the phytoplankton biomass or production as an error term in the experimental design. Ultimate effects of the treatments have in the present case to be sought in the data after integration of the daily variation as we did in our investigation on the dose-response relationships between net nutrient addition and mean values of chlorophyll and primary production.

\section{Phytoplankton biomass and production}

Outcomes of similar experiments performed in the MERL (Marine Ecosystems Research Laboratory, University of Rhode Island, Kingston, RI, USA) mesocosms in 1982-1983 (Oviatt et al. 1986, Keller 1988) were compared with the present results. In order to cope with the different experimental duration in the MERL mesocosms and here, comparisons were made on the basis of mean daily addition (whole addition divided by experiment days). For nitrogen additions equalling 6 and $10 \mathrm{mmol} \mathrm{N} \mathrm{m}{ }^{-2} \mathrm{~d}^{-1}$, mean chl a concentrations in the MERL mesocosms were ca 22 and $32 \mathrm{\mu g} \mathrm{l}^{-1}$ (extracted graphically from Keller 1988 and rescaled for the mesocosm size). Those values were close to the results obtained in the present experiments (Fig. 10a) and reproduced a similar response of the chl a concentrations to the increase in nitrogen addition (+10 and $+15 \mu \mathrm{g} \mathrm{chl} \mathrm{a} \mathrm{l}^{-1} \mathrm{mmol}^{-1} \mathrm{~N} \mathrm{~d}^{-1}$ added in MERL and present experiments respectively).
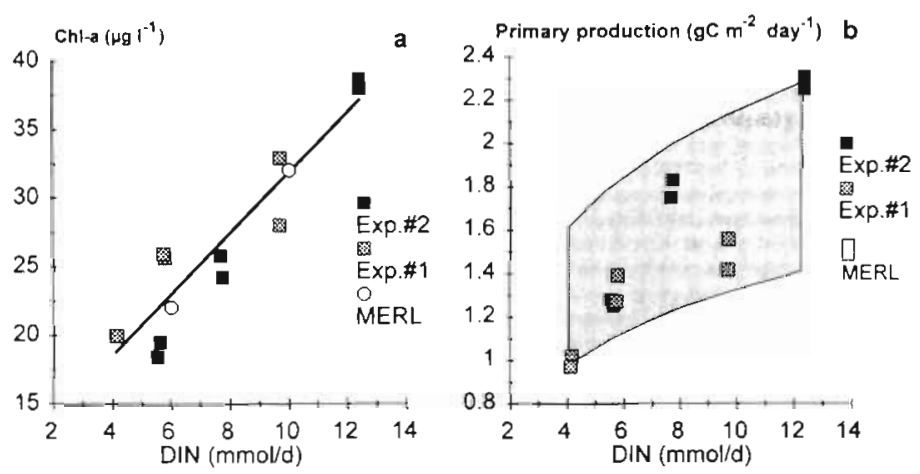

Fig. 10. (a) Chl a concentrations in Expts 1 and 2 compared with values from the MERL experiment for similar N-load (from Keller 1988). (b) Primary production compared with ranges predicted by the model from MERL experiments (from Oviatt et al. 1986) 
From the same MERL experiment, Oviatt et al. (1986) constructed a log-linear relationship between the water column production ( $\left.\mathrm{PP}, \mathrm{g} \mathrm{O}_{2} \mathrm{~m}^{-2} \mathrm{yr}^{-1}\right)$ and the DIN addition (DIN, mmol $\mathrm{m}^{-2} \mathrm{~d}^{-1}$ ) as: $P P=386 \ln (\mathrm{DIN})$ +491 . For comparison with our results, yearly $\mathrm{O}_{2}$ production was transformed into daily $\mathrm{C}$ production by using 2 assimilation coefficients $\left(\mathrm{dO}_{2} / \mathrm{dCO}_{2}\right), 1.25$ and 2 , estimated as upper and lower boundary values for our mesocosms from previous experiments (Prins et al. 1994). Production rates estimated from the MERL experiments were further corrected for the transmission factor $(70 \%)$ of the diffusor placed on top of each mesocosm. Production rates were estimated over the $\mathrm{N}$ addition range used in our mesocosm experiments ( 4 to $14 \mathrm{mmol} \mathrm{m} \mathrm{m}^{-2} \mathrm{~d}^{-1}$ ). The ranges for the primary production predicted from the MERL model were close to the values measured in the present experiment (Fig. 10b).

\section{Representativeness of the dose-response model}

When Eq. (3) makes sense, a should represent the mean quantum yield efficiency $\left(\mathrm{g} \mathrm{C} \mathrm{mol}^{-1}\right.$ photons $\mathrm{m}^{-2}$ ) and $b$ the nitrogen addition (mmol) that could support $50 \%$ of the maximum phytoplankton production at a given light level. Saturation of primary production with $\mathrm{N}$-addition could occur together with a switch in the nature of nutrient limitation: from $\mathrm{N}$ - to P- or Si-limitation.

The value found for a $\left(0.141 \mathrm{~g} \mathrm{C} \mathrm{mol}^{-1}\right.$ photons $\left.\mathrm{m}^{-2}\right)$ was compared to the slopes of the $P / I$ curves $(1 / \mathrm{c}$ in Eq. 2) measured with ${ }^{14} \mathrm{C}$-incubations during these experiments after rescaling for homogeneity of the units. The $P / I$ curve slopes were between 0.064 and $0.160 \mathrm{~g} \mathrm{C} \mathrm{mol}^{-1}$ photons $\mathrm{m}^{-2}$. The value of a fitted with Eq. (3) $\left(\mathrm{g} \mathrm{C} \mathrm{mol}^{-1}\right.$ photons $\left.\mathrm{m}^{-2}\right)$ was in the range measured with the ${ }^{14} \mathrm{C}$-incubations.

Following the fitted model, when $\mathrm{N}$-additions reached $270.9 \mathrm{mmol} N$, primary production equalled $50 \%$ of the maximal production predicted by the term $a \cdot I R R$. Until this level of $\mathrm{N}$-addition, primary production increased almost linearly with $\mathrm{N}$-addition whereas saturation of the curve intensified for larger $\mathrm{N}$-additions. Our hypothesis was that, above a given $\mathrm{N}$-addition threshold, primary production could become limited by one of the other macro-nutrients, $\mathrm{P}$ or Si. A switch from $\mathrm{N}$ - to $\mathrm{P}$ - or Si-limitation should be indicated by values of the molar ratios N/P and N/Si larger than the standard molar ratios of 16 and 1 respectively (Gillbricht 1988). For each experiment the ratios were calculated between the calibrated value for $b$ and the additions of $\mathrm{P}$ and $\mathrm{Si}$ made in the same experiments (Table 3 ). The corresponding $\mathrm{N} / \mathrm{P}$ ratios were close to the standard molar ratio and the $\mathrm{N} / \mathrm{Si}$ ratios twice as high. This result indicated that for $\mathrm{N}$-addition exceed-
Table 3. Net silicate and phosphorus additions and corresponding nutrient ratios (N/P, N/Si) for primary production half-saturation predicted from Eq. (3) fitted to the mesocosm experiments

\begin{tabular}{|lcccc|}
\hline Expt & DIP (mmol) & N/P & Silicate (mmol) & N/Si \\
\hline 1 & 17 & 16 & 129 & 2.1 \\
2 & 21 & 13 & 100 & 2.7 \\
Mus1 & 20 & 13 & 100 & 2.7 \\
\hline
\end{tabular}

ing $b$, primary production should become potentially limited by $\mathrm{P}_{-}$(non-diatoms) and Si-availability (diatoms).

As a result, the values fitted for $a$ and $b$ in Eq. (3) appeared to be realistic estimates for the corresponding phytoplankton growth parameters. This supports the model that described phytoplankton production as a combination of a saturation function of DIN loading and a linear function of light.

\section{The nature of nutrient limitation}

Whether one nutrient was limiting for phytoplankton development or not was determined by comparing its concentration and corresponding ratio to other nutrients to values from the literature. While such an approach contains a lot of uncertainty, results of the present experiments showed good agreement between phytoplankton growth and nutrient availability. Furthermore, the saturation model fitted to our data predicted values for critical molar ratios close to literature values for phytoplankton molar composition.

When nitrogen limitation of phytoplankton is addressed, the use of dissolved organic nitrogen (DON) as a possible $\mathrm{N}$-source could also be considered. In the present experiments, DON concentrations were between 10 and $25 \mu \mathrm{M}$, did not differ among the treatments and increased with time. The relation shown between primary production and the DIN addition suggested that phytoplankton may not be able to make a significant use of the organic fraction of the nitrogen pool.

\section{Diatom response to the treatment}

Significant differences in diatom concentrations among the treatments were found on the last days of both experiments: highest concentrations in Treatments $\mathrm{H}$ and $\mathrm{M}$ respectively in Expts 1 and 2. It was also observed that in the second part of both experiments, diatoms in $\mathrm{H}$ treatments had more chloroplasts than in the $M$ and $L$ treatments. This observation 
agrees with the results of Tett et al. (1975), which showed that nutrient deficient phytoplankton (in cultures and in the field) showed a decrease in the chlorophyll/carbon ratio.

Diatom species composition shifts in the second part of both experiments did not differ much among the treatments but occurred in all cases at decreased $\mathrm{N}$ and Si concentrations. The shift in the diatom species composition observed during Expt 2 compared well with observations made in a previous mesocosm experiment (summer 1993), where, at low P and Si concentrations, Rhizosolenia delicatula declined and was replaced by Leptocylindrus danicus (Escaravage et al. 1996). Whereas L. danicus appeared to be a good competitor for low nutrient concentrations (either N, P or Si) in the summer experiments run in 1993 and 1994, it did not become dominant in Expt 1 (run in May-June) since diatoms were dominated by Eucampia zoodiacus, Nitzschia seriata and Rhizosolenia sp.

\section{Phaeocystis sp. response to the treatment}

In both experiments Phaeocystis sp. peak concentrations numerically dominated the flagellates. Whereas Phaeocystis sp. peak concentrations were reached in Expt 2 around Day 20 (during the colonial bloom), they occurred during the last week in Expt 1 (after the colonial bloom, mainly solitary cells). Nevertheless, in both cases, the highest cell concentrations were measured in Treatment $H$. It can be concluded that the lower nitrogen availability in Treatments $M$ and $L$ (in both experiments) limited the Phaeocystis sp. peak concentrations. Control of Phaeocystis sp. concentrations by inorganic nitrogen availability has also been observed by Lancelot (1983) in the Southern Bight of the North Sea, where depletion of DIN induced the decline of the Phaeocystis sp. spring bloom. The author related this decline to an intensification of the extracellular release (up to $80 \%$ of the photo-assimilated C) at low nitrogen concentrations.

Phaeocystis sp. colony peak concentrations showed differences among treatments similar to flagellate cell concentrations: similar in all treatments on Day 15 in Expt 1, higher in Treatment $\mathrm{H}$ than in other treatments between Days 15 and 20 in Expt 2. It can be assumed consequently that Phaeocystis sp. colonies developed in Expt 1 before the establishment of nitrogen limitation whereas the colony bloom occurred in Expt 2 under nitrogen limitation. These results agree with those of Riegman et al. (1992), who concluded, from culture experiments, that colonial blooms of Phaeocystis sp. could be expected to appear in nitrogen-controlled environments where nitrate is the predominant nitrogen source.

\section{Diatom/flagellate competition for nitrogen}

Phaeocystis sp. was responsible for most of the dynamics within the flagellate group. In both experiments, after the colonial bloom had collapsed, Phaeocystis sp. was mainly represented by solitary cells which competed for nitrogen with the new diatom community developing in all mesocosms during the last week of the experiment. In the last week of Expt 1 no significant shift in the flagellate/diatom ratio occurred since both groups developed similarly in each treatment. In Expt 2 diatom concentrations increased in most treatments after Day 20, whereas flagellate (Phaeocystis sp. solitary cells) concentrations generally decreased or stabilized. Due to the relatively short duration of the nitrogen limiting period during the experiment the outcome of the competition for this nutrient is not known. Nevertheless it can be concluded that the nitrogen depletion induced a shift towards diatom (mainly Leptocylindrus danicus) dominance. This result seems to conflict with the competition experiment by Riegman et al. (1992), where Phaeocystis sp. proved to be a good competitor under $\mathrm{N}$-limitation. As suggested by these authors, such a discrepancy could result from differences in scale and complexity between their laboratory cultures and more complex systems like our mesocosms, involving more phytoplankton species and possible interactions with other trophic levels.

A similar shift in species composition as in Expt 2 was observed during a previous mesocosm experiment (Escaravage et al. 1996), when phosphorus depletion induced a sharp decrease in Phaeocystis sp. concentrations whereas diatoms (mainly Leptocylindrus danicus) continued to develop. In a third mesocosm experiment (Escaravage et al. 1995) a massive Phaeocystis sp. colonial bloom developed in mesocosms where $\mathrm{N}$ and $\mathrm{P}$ were regularly added to prevent any limitation. From these mesocosm experiments, Phaeocystis sp. proved to be a bad competitor with diatoms for both $\mathrm{N}$ and $\mathrm{P}$ and to develop better at non-limiting concentrations of $\mathrm{N}$ and $\mathrm{P}$ and when diatoms were Si-limited.

\section{Phytoplankton species succession in mesocosms and in the field}

Phaeocystis sp. colonial blooms develop in the North Sea coastal waters after collapse of the Si-limited diatom spring bloom (Gieskes \& Kraay 1975, van Bennekom et al. 1975, Cadée \& Hegeman 1982). In both of our experiments during the first 5 to $10 \mathrm{~d}$, the phytoplankton was dominated by diatoms. Termination of the diatom bloom was presumably due to Si-limitation and coincided with the development of the Phaeocystis sp. bloom. 
The wane of the Phaeocystis sp. spring bloom in the North Sea has been attributed to nitrogen depletion (Lancelot \& Mathot 1987). Van Boekel et al. (1992) found that cell lysis induced by nitrogen limitation could be responsible for this decline of the Phaeocystis sp. colonial bloom. In both experiments collapse of the Phaeocystis sp. colonial bloom occurred in all treatments simultaneously with a decrease of the irradiance and at low nitrogen concentrations. From field observations and laboratory culture, Peperzak (1993) established that no colonies were formed under $22 \mathrm{~mol} \mathrm{pho-}$ tons $\mathrm{m}^{-2} \mathrm{~d}^{-1}$ and that decay of the colonial bloom occurred through a conjugated effect of reduced light energy and nutrient stress. In the present experiments, the colony peak concentrations coincided with maximum irradiance around $30 \mathrm{~mol}$ photons $\mathrm{m}^{-2} \mathrm{~d}^{-1}$ and collapse of the blooms occurred at irradiances below $15 \mathrm{~mol}$ photons $\mathrm{m}^{-2} \mathrm{~d}^{-1}$, i.e. under the threshold determined by Peperzak (1993) (Figs. 1 \& 9).

After the Phaeocystis sp. bloom collapsed, a second diatom bloom took place in both experiments, dominated by Nitzschia seriata, Eucampia zoodiacus, and Rhizosolenia sp. (replacing $N$. delicatissima) during the first experiment and by Leptocylindricus danicus during the second experiment. Bakker et al. (1990) observed a similar succession in the mouth of the Oosterschelde (SW Netherlands), where N. seriata, E. zoodiacus, and Rhizosolenia sp. reached significant biomass from May onwards whereas $L$. danicus became important between July and August (Bakker et al. 1990). This agreed with results of a principal components analysis on phytoplankton abundances in the Dutch coastal waters by Leewis (1985), where $N$. seriata and $L$. danicus appeared to be characteristic species for the months April and June respectively. This points out the influence of season and related specific optima (irradiance, temperature) on the outcome of the diatom competition for nutrient ( $\mathrm{N}$ and/or $\mathrm{Si}$ ) and could explain the different phytoplankton developments observed in Expts 1 and 2.

\section{CONCLUSIONS}

Whereas phytoplankton biomass (chl a) increased linearly with the nitrogen addition, primary production became limited by light and/or other nutrients when nitrogen additions were high. Both phytoplankton biomass and production were on the same order of magnitude as values measured in the MERL experiments.

The $\mathrm{N}$-addition reduction induced a shift towards a diatom dominance since Phaeocystis sp. apparently did not manage to compete for nitrogen with the diatom Leptocylindricus danicus.
When all our mesocosm experiments are considered (Escaravage et al. 1995, 1996, present study) the results corroborate the hypothesis by Cadée \& Hegeman (1986) that the increase of Phaeocystis sp. in the Dutch coastal water in recent decades is related to an increase in eutrophication ( $\mathrm{N}$ - and $\mathrm{P}$-additions) rather than a shift in the $\mathrm{N} / \mathrm{P}$ or $\mathrm{NH}_{4}{ }^{+} / \mathrm{NO}_{3}{ }^{-}$ratios as suggested by Riegman et al. (1992).

Acknowledgements. Special thanks are due to A. J. Pouwer for his invaluable involvement in the daily management of the mesocosms. All chemical analyses were carried out by $W$ Schreurs and his staff at RIKZ laboratory. We also thank all members of the BEON 'EUTRO ${ }^{\circ} \mathrm{ECO}$ project group for stimulating discussions. The research was financed by RIKZ in the framework of the BEON ${ }^{*}$ EUTRO ${ }^{*}$ ECO project. This is publication no. 2506 of the Netherlands Institute of Ecology, Centre for Estuarine and Coastal Ecology.

\section{LITERATURE CITED}

Bakker C, Herman PMJ, Vink M (1990) Changes in seasonal succession of phytoplankton induced by the storm-surge barrier in the Oosterschelde (S.W. Netherlands). J Plankton Res 12(5):947-972

Cadée GC, Hegeman J (1986) Seasonal and annual variation in Phaeocystis pouchetii (Haptophyceae) in the westernmost inlet of the Wadden Sea during the 1973 to 1985 period. Neth J Sea Res 20(1):29-36

Cadée GC, Hegeman J (1993) Persisting high levels of primary production at declining phosphate concentrations in the Dutch coastal area (Marsdiep). Neth J Sea Res 31(2): $147-152$

De Vries I, Duin RNM, Peeters JCH, Los FJ, Bokhorst M, Laane RWPM (1998) Patterns and trends in nutrients and phytoplankton in Dutch coastal waters: comparison of time series analysis, ecological model simulations and mesocosm experiments. ICES J Mar Sci 55:620-634

Eilers PHC, Peeters JCH (1988) A model for the relationship between light intensity and the rate of photosynthesis in phytoplankton. Ecol Model 42:199-215

Escaravage V, Peperzak L, Prins TC, Peeters JCH, Joordens JCA (1995) The development of a Phaeocystis bloom in a mesocosm experiment in relation to nutrients, irradiance and coexisting algae. Ophelia 42:55-74

Escaravage V, Prins TC, Smaal AC, Peeters JCH (1996) The response of phytoplankton communities to phosphorus input reduction in mesocosm experiments. J Exp Mar Biol Ecol 198:55-79

Gieskes WWC, Kraay GW (1975) The phytoplankton spring bloom in Dutch coastal waters of the North Sea. Neth J Sea Res 9(2):166-196

Gillbricht M (1988) Phytoplankton and nutrients in the Helgoland region. Helgol Wiss Meeresunters 42:435-467

Keller AA (1988) Estimating phytoplankton productivity from light availability and biomass in the MERL mesocosms and Narragansett Bay. Mar Ecol Prog Ser 45:159-168

Leewis RJ (1985) Phytoplankton off the Dutch coast: a base line study on the temporal and spatial distribution of species in 1974 and 1975. Thesis, University of Nijmegen. Rijkswaterstaat Communications no. 42, The Hague

Lancelot C (1983) Factors affecting phytoplankton extracelluIar release in the Southern Bight of the North Sea. Mar Ecol Prog Ser 12:115-121 
Lancelot C, Mathot S (1987) Dynamics of a Phaeocystis-dominated spring bloom in Belgian coastal waters. I. Phytoplankton activities and related parameters. Mar Ecol Prog Ser 37:239-248

Monod J (1942) Recherches sur la croissance des cultures bactériennes. Hermann, Paris

Officer CB, Ryther JH (1980) The possible importance of silicon in marine eutrophication. Mar Ecol Prog Ser 3:83-91

Oviatt CA, Keller AM, Sampou PA, Beatty LL (1986) Patterns of productivity during eutrophication: a mesocosm experiment. Mar Ecol Prog Ser 28:69-80

Peeters JCH, Peperzak L (1990) Nutrient limitation in the North Sea: a bioassay approach. Neth J Sea Res 26(1): 61-73

Peeters JCH, Haas H, Peperzak L, Wetsteyn LPMJ (1991) Limiting factors for phytoplankton in the North Sea. Water Sci Technol 24(10):261-267

Peeters JCH, Arts F, Escaravage V, Haas HA, De Jong DEA, Van Loon R, Moest B, Van Der Put A (1993a) Studies on light climate, mixing and reproducibility of ecosystem variables in mesocosms: consequences for the design. In: Peeters JCH, Joordens JCA, Smaal AC, Nienhuis PH (eds) The impact of marine eutrophication on phytoplankton and benthic suspension feeders: results of a mesocosm pilot study. Report DGW-93.039, NIOO-CEMO-654, Middelburg, p 7-23

Peeters JCH, Haas HA, Peperzak L, de Vries I (1993b) Nutrients and light as factors controlling phytoplankton biomass on the Dutch Continental Shelf (North Sea) in 1988-1990. Internal Report DGW-93.004, National Institute for Coastal and Marine Management/RIKZ, Middelburg

Peeters JCH, Los FJ, Jansen R, Haas HA, Peperzak L, de Vries I (1995) The oxygen dynamics of the Oyster Ground, North Sea. Impact of eutrophication and environmental conditions. Ophelia 42:257-288

Peperzak L (1993) Daily irradiance governs growth rate and colony formation of Phaeocystis (Prymnesiophyceae). J Plankton Res 15(7):809-821

Prins TC, Escaravage V, Pouwer AJ, Haas HA (1994) Description of mesocosms, methods and comparison with North Sea conditions. In: Smaal AC, Peeters JCH, Haas HA, Heip CHR (eds) The impact of marine eutrophication on phytoplankton and benthic suspension feeders. Progress report I: Results of mesocosm experiments with reduced Pload and increased grazing pressure. Report RIKZ-94.035. NIOO-CEMO 1992-4, Middelburg, p 10-40

Prins TC, Escaravage V. Smaal AC, Peeters JCH (1995a) Nutrient cycling and phytoplankton dynamics in relation

Editorial responsibility: Otto Kinne (Editor),

Oldendorf/Luhe, Germany to mussel grazing in a mesocosm experiment. Ophelia 41 : $289-315$

Riegman R, Noordeloos AAM, Cadée GC (1992) Phaeocystis blooms and eutrophication of the continental coastal zone of the North Sea. Mar Biol 112:479-484

Scheldon RW, Prakash A, Sutcliffe WH (1972) The size distribution of particles in the ocean. Limnol Oceanogr 17 : $327-340$

Schöllhorn E، Granéli E (1993) Is the increase of flagellates in coastal waters caused by changes in ratios of $\mathrm{N}, \mathrm{P}$ and $\mathrm{Si}$ ? In: Smayda TJ, Shimizu Y (eds) Toxic phytoplankton blooms in the sea. Elsevier Science Publishers BV, Amsterdam, p 811-817

Smayda TJ (1990) Novel and nuisance phytoplankton blooms in the sea: evidence for a global epidemic. In: Granéli $\mathrm{E}$, Sundström B, Edler L, Anderson DM (eds) Toxic marine phytoplankton. Elsevier, Amsterdam, p 29-40

Tett P, Cotrell JL, Trew DO, Wood BJB (1975) Phosphorus quota and the chlorophyll:carbon ratio in marine phytoplankton. Limnol Oceanogr 20(4):587-603

Utermöhl H (1958) Zur Vervollkomnung der quantitativen Phytoplankton Methodik. Mitt Int Verein Limnol 9:1-39

Van Bennekom AJ, Gieskes WWC, Tijssen SB (1975) Eutrophication of Dutch coastal waters. Proc R Soc Lond Ser B Biol Sci 189:359-374

Van Boekel WHM, Hansen FC, Riegman R, Bak RPM (1992) Lysis induced decline of a Phaeocystis spring bloom and coupling with the microbial food web. Mar Ecol Prog Ser 81:269-276

Veldhuis MJW, Colijn F, Venekamp LAH (1986) The spring bloom of Phaeocystis pouchetii (Haptophyceae) in Dutch coastal waters. Neth J Sea Res 20(1):37-48

Veldhuis MJW, Colijn F, Admiraal W (1991) Phosphate utilization in Phaeocystis pouchetii (Haptophyceae). PSZN I: Mar Ecol 12:53-62

Vollenweider RA, Rinaldi AG, Montanari G (1992) Eutrophication, structure and dynamics of a marine coastal system: results of ten years monitoring along the Emilia Romagna coast (Northwest Adriatic Sea). In: Vollenweider RA, Marcheti $R$, Viviani R (eds) Marine coastal eutrophication. Elsevier, Amsterdam, p 63-106

Wetsteyn LPMJ, Vink-Lievaart M (1995) Zooplankton dynamics in $\mathrm{N}$-manipulated mesocosms. In: Peeters JCH, Smaal AC, Haas HA, Heip CHR (eds) The impact of marine eutrophication on phytoplankton and benthic suspension feeders. Progress report II: Results of mesocosm experiments with reduced $\mathrm{N}$-load and increased grazing pressure. Report RIKZ-95.048, NIOO-CEMO 1993-5, Middelburg, p 82-113

Submitted: January 30, 1997; Accepted: November 18, 1998 Proofs received from author(s): March 17, 1999 